\title{
Predictors of e-democracy applicability in Turkish K-12 schools
}

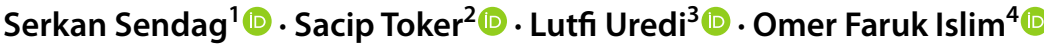

Received: 5 February 2021 / Accepted: 8 September 2021 / Published online: 22 September 2021 (c) The Author(s), under exclusive licence to Springer Science+Business Media, LLC, part of Springer Nature 2021

\begin{abstract}
Today, the COVID-19 pandemic has paved the way for a more democratic climate in K-12 schools. Administrators and teachers have had to seek out new ways through which to interact. This raises two questions; "What about the quality of interaction and participation in decision-making?" and "Which factors affect the level of participation in decision-making?" The aim of the current research is to determine the factors that predict the applicability level of e-democracy (i.e., "reporting and declaring opinions" and "decision-making") in K-12 schools. An associational research design was used in order to attain the main goal of the study, with Discriminant Function Analysis (DFA) technique used to analyze the factors predicting the applicability level of e-democracy. Data were collected from a total of 765 inservice K-12 teachers through a questionnaire developed by the researchers. DFA results showed "motivation to participate," "the level of participatory democracy in the country," and higher levels of the "use of Twitter" as the significant determinants of different levels of e-democracy application. Moreover, the results also indicated that those participants with the belief of e-democracy's applicability at the decision-making level found the "motivation level of stakeholders" to be the most critical. Their level of Twitter use was higher. They also believed that the level of participatory democracy in the country was at a higher level. Another result of the DFA pointed to "security and ethical issues," and lower levels of the "use of Twitter" as factors differentiating the group believing that e-democracy can be applicable with reporting and the declaration of opinions to administrators from the other groups. The discussions highlighted the critical role of participation level in e-democracy within K-12 schools.
\end{abstract}

Keywords e-Democracy $\cdot$ Inservice teachers $\cdot$ e-Participation $\cdot$ Educational management . Online social media

Omer Faruk Islim

islim@mersin.edu.tr

Extended author information available on the last page of the article 


\section{Introduction}

E-democracy is an ongoing topic of discussion in developing countries. Nevertheless, e-democracy is generally a relatively new concept in many countries, including Turkey, hence there is only a small amount of literature on the topic. Therefore, determining whether or not e-democracy is understood and its applicability within the school environment is of significant interest.

E-democracy has emerged as a new form of democracy that accelerates the democratization process through information and communication technologies (ICTs). The evolution of information technology has initiated industrialization and modernization in developing countries, which has created a motivation to develop democratic practices (Van Long, 2020). By using electronically accessible e-participation tools, the democratic process has shifted from a mode of representation to a mixed mode in which the public participates in the political process more efficiently and with a capacity that has not previously been witnessed. The earlier political systems relied upon an impractical representation process, whereby the public was not afforded the same level of equal opportunity (Clive, 2012). Today, citizens can participate in democratic change processes, have their say, and become active in decision-making activities (Medimorec et al., 2010) thanks to the emergence of electronic tools such as e-mail, e-forums, e-polls, and other collaborative tools (Abu-Shanab \& Al-Dalou', 2012). In this context, e-democracy (or digital democracy) with flexible and interactive tools and enriched environments are considered ideal to help democracy achieve its goals, providing a suitable space for "participation", and developing the possibility of a stronger democracy. Therefore, participation in e-democracy has always been the core topic of the field. Many authors have investigated and argued different dimensions of participation (Bailey \& Ngwenyama, 2011; Şendag \& Toker, 2016; Shelley II et al., 2006; Shirazi et al., 2010). However the quality level of participation still remains a topic of concern to be investigated in more detail. Besides, much has been done to identify participation in different contexts (Karickhoff \& Howley, 1997; Macintosh et al., 2003; Oral, 2008) while the "quality of participation" in e-democracy in educational settings seems a bit neglected.

In his pioneering work, "Democracy in Education," Dewey (1903) stated that democratically organized schools play a remarkable role in the development of democratic life beyond the school gates. The education system, and especially $\mathrm{K}-12$ schools, have a vital role to play in the creation and dissemination of a more robust democratic culture. The participation of school stakeholders (i.e., teachers, parents, and students) in schools' decision-making processes has always attracted significant attention (Dewey, 1903; Yiğit \& Çolak, 2010). However, a democratic school environment does not happen in a day, it needs a lot of time and effort. The main responsibility to build a true democratic school environment belongs to policy makers and school administrators where students, teachers, parents and more people are stakeholders. A democratic school environment is a result of a collective effort of all stakeholders (Mompoint-Gaillard et al., 2019). As a result, 
promoting the quality of participation in e-democracy in K-12 schools can play a significant role in improving democratic climate.

For more than 10 years, e-democracy in education has become a seminal topic of research, as well as an area of practice and development (Kocór et al., 2017; Peters \& Jandrić, 2017; Şendağ, 2010; Yiğit \& Çolak, 2010). However, the literature on the quality of participation in e-democracy in K-12 schools is very limited. Therefore, some fundamental questions remain unanswered: "To what extent can participation in e-democracy be applicable in K-12 schools?" and "What premises may affect the different levels of participation in e-democracy in K-12 Schools?".

The extent of participation in e-democracy within K-12 schools may occur in two main levels: (a) "initial level": is a level of e-democracy where the stakeholders merely report their opinions/ideas/suggestions (no interaction is necessarily to be done between them) to the administrators, (b) "deliberative level": is a higher level of e-democracy, in which stakeholders reach a decision by arguing/discussing. The current study aimed to examine the significant discriminant factors for both the realization of "initial level e-democracy", and "deliberative level of democracy" in Turkish K-12 schools by surveying the teachers' responses. Specifically, the aim of the current study is to determine the factors predicting the applicability of both initial and deliberative e-democracy in K-12 schools. More specifically, which of the following factors:

- antecedents of e-democracy in schools (motivation to participate, security and ethical issues, administrative issues, and infrastructure and platforms),

- demographic information (gender, school type currently working, years of experience in teaching, education level),

- technology information (use of Facebook and Twitter, daily use hours of Internet, basic computer and Internet skills, willingness to use computer and Internet),

- willingness to teaching,

- level of participatory democracy in the country, and

- sharing on social media,

are significant in discriminating the participants' beliefs as:

1. e-democracy can never be applicable or,

2. e-democracy can be applicable at initial level or,

3. e-democracy can be applicable at a deliberative level.

\subsection{The participation in e-democracy}

Earlier attempts to define the term e-democracy have evolved around communications between citizens and politicians or administrators (Chadwick, 2003). Previous attempts to realize e-democracy have occured in the form of electronic voting. In the literature, different terms and concepts are used to define this means of democracy such as e-democracy, digital democracy, or cyber democracy (Musiał-Karg \& Kapsa, 
2019). Ronchi (2019) suggests that the term e-democracy encompasses a wide range of political activities from e-governance to e-voting and e-participation, and supports the strengthening of public participation and direct democracy. The concept of e-democracy (or cyber democracy) refers to adapting a wide range of computer technologies to democracy (Ferdinand, 2003).

E-democracy conceptually embraces direct democracy, but the way to implement democracy is to methodically adopt an online digital system (Çabuk et al., 2016). "Participation" is the fundamental concept for e-democracy. The primary purpose of e-democracy is to switch from representative democracy to participatory democracy, and it should be built upon a level of participation.

A great deal of research has been done to identify the participation in e-democracy (the types of participation (i.e. anonymous and onymous) (Sendag \& Toker, 2016), ways of participation (i.e. e-forums, e-consultation, e-referenda, e-mailing, online decision-making, e-campaigning, e-voting, and e-petitioning) (Coleman \& Norris, 2005; Şendağ, 2010, 2014), factors affecting participation such as political knowledge, political talk, digital integrity, digital citizenship, digital divide, mobile device use, ICT use, gender, income, education level, and age (Bailey \& Ngwenyama, 2011; Şendağ, 2010; Şendağ \& Toker, 2016; Shelley II et al., 2006; Shirazi et al., 2010). A considerable amount of research on the participation of pre-service teachers in e-democracy have been done (Karickhoff \& Howley, 1997; Macintosh et al., 2003; Oral, 2008; Şendağ, 2010; Şendă̆ \& Toker, 2016; Ünlü, 2017; Yiğit \& Çolak, 2010) while the same is not true for inservice teachers (Kolfschoten, 2012; Park, 2018). Moreover, the quality of participation in e-democracy applications in educational settings refers to a crucial research gap to fulfill. In this context, deliberative e-democracy can serve to improve the quality of participation in e-democracy.

Beyond the issues related to the system, "deliberative democracy" has gained attention through the development and proliferation of electronic media. While some authors believe that participatory and deliberative democracy are separated by certain characteristic distinctions (Mutz, 2006), their goals remain similar (Mutz, 2006; Wojcieszak et al., 2010), which is to reach a decision. Deliberative democracy focuses more on the debate, whilst participatory democracy emphasizes the outcome (decision). As a result, "deliberative e-democracy", relatively a new concept, requires a higher level of citizen involvement, and interactivity in e-democracy applications. Based on the participation quality, Päivärinta and Sæbø, (2006) defines initial level of e-democracy applications as "liberal (Which we call "initial e-democracy" within the context of the study) where citizens have the opportunity to give suggestions to the administrators/politicians, however, in the case of deliberative e-democracy, ideas needs to be argued before decision making. Governments/politicians/officers set the agenda in both liberal and deliberative levels. However, "direct e-democracy" is the highest level that citizens set the agenda (Mærøe et al., 2021; Päivärinta \& Sæbø, 2006), which is beyond the scope of the current study. 


\subsection{Applicability of e-democracy in K-12 schools}

In Turkey, the main policy maker about K-12 schools is the Ministry of National Education, where all schools in the country have to obey the rules decided by them. Although there are a number of policies about the operations of the schools including democratic elections such as parent-teacher association and student delegate of the school there was no policy about e-democracy. However, school administrators or the provincial directorate of the Ministry of National Education might ask the opinion of teachers or students via social media or survey applications. Considering the structure of current educational settings, realizing "direct e-democracy" applications may not be suitable while initial and deliberative e-democracy are possible to be applied in K-12 schools in Turkey if the certain factors are to be justified for implementation. Therefore, in reviewing the current literature, our primary purpose was to reveal the potential determinants of e-democracy levels in K-12 schools.

While the critical role of factors that might affect participation in e-democracy has been extensively discussed and described (Şendağ \& Toker, 2016; Sennett, 1999), the potential role of motivation to participate seems to have been somewhat neglected. Motivation is an inner instinct that can be affected by a variety of different factors, which is considered to be beyond the scope of the current study. However, the extent of the willingness/disposition towards participation could be a significant predictor for participation at any level. Moreover, some studies have shown that teachers' intrinsic motivation to teach may affect their performance (Pelletier et al., 2002). Therefore teachers' willingness to teach may have a potential of affecting issues related to her/his profession.

Previous studies in the literature also point to the role of ICTs such as email and social networking websites as enabling factors in e-democracy participation (Coleman \& Norris, 2005; Şendağ, 2010). ICT makes the operation of democracy both low-cost and convenient, as well as facilitating the expansion of the democratic space that reflects the e-democracy characteristics of ordinary people. Traditional democracy, however, has much higher costs and complex procedures with elitist features; yet, unlike e-democracy, it has relative proximity to the voters. Besides, e-democracy is still not widely adopted in developing countries for various reasons (Ayo et al., 2015; Oni et al., 2017; Shat \& Pimenidis, 2017; Toots, 2019). For example, certain economic difficulties are evident in developing countries regarding the accessing of e-democracy applications (Naranjo-Zolotov et al., 2019a, 2019b; Toots, 2019). Among the most common ICTs, the role of social networking platforms has become prominent. Regarding social networking platforms, the critical role of security and ethics should also be taken into account (Şendağ \& Toker, 2016). On the other side, the attitudes of administrators, as well as the access and the infrastructure for ICTs may well be of concern to teachers, whose primary purpose is to push and encourage high levels of e-democracy. For example, the question of which specific social platform could be the most important factor in determining the quality level of participation in the e-democracy process. It seems that different social networking platforms have the potential to imply different perceptions about participation in e-democracy. 


\section{Method}

\subsection{Research design}

This study was designed as a correlational study (Creswell, 2012), which allowed the researchers to evaluate the relationships and impacts among independent and dependent variables.

\subsection{The instrument}

The instrument contained three sections: (1) demographic information, (2) the antecedents of applicability of e-democracy in schools, and (3) the level of applicability of e-democracy in schools. Each section will be explained below in detail.

\subsubsection{Participants}

The population of the study was all teachers employed at the public primary, secondary, and high schools in a metropolitan city at the south of Turkey. Since the random sampling was not plausible due to the time and resource constraints, a cluster sampling of the schools conveniently available to the researchers was applied. All schools were selected from the city center, and the schools were selected as $30 \%$ primary, $30 \%$ secondary, and $40 \%$ high schools. Table 1 illustrates demographics of inservice teachers who participated in the present study.

The majority of inservice teachers were female $(53.11 \%)$. The highest number of inservice teachers were working at high school $(37.87 \%)$, and the lowest was primary school $(26.58 \%)$. The majority of inservice teachers had undergraduate degrees $(80.18 \%)$. More than $95.0 \%$ of inservice teachers expressed their computer skills as intermediate or higher level. For internet skills, the same situation of computer skills was true. More than $90.0 \%$ of inservice teachers spent more than 1 and $2 \mathrm{~h}$ on the internet daily. The majority of inservice teachers were not using Facebook (68.72\%); whereas, they were using Twitter at $73.53 \%$.

From the original 920 respondents, 142 cases were dropped due to missing data, which appeared to be randomly scattered throughout the groups and predictors. An additional 13 cases were identified as multivariate outliers $(p<0.001)$ and were subsequently also deleted. The outlier cases were 8, 3, and 2 from never applicable, applicable with reporting and declaration to managers, and applicable within online platforms, respectively.

This section included 13 questions listed below with their corresponding options:

- Gender: Female or Male

- The current school working: Primary, Secondary, or High School

- Years of experience

- Level of education: Associate, Undergraduate, Graduate or Doctoral Degree

- Use of Facebook: Yes or No 
Table 1 Demographics of the participants

\begin{tabular}{|c|c|c|c|}
\hline & & $\mathrm{f}$ & $\%$ \\
\hline \multirow[t]{2}{*}{ Gender } & Male & 430 & 46.89 \\
\hline & Female & 487 & 53.11 \\
\hline \multirow[t]{3}{*}{ School working } & Primary school & 240 & 26.58 \\
\hline & Secondary school & 321 & 35.55 \\
\hline & High school & 342 & 37.87 \\
\hline \multirow[t]{4}{*}{ Level of education } & ÖN LİSANS & 77 & 8.43 \\
\hline & LİSANS & 732 & 80.18 \\
\hline & YÜKSEK LİSANS & 98 & 10.73 \\
\hline & DOKTORA & 6 & .66 \\
\hline \multirow[t]{5}{*}{ Computer skills } & Beginner & 46 & 5.01 \\
\hline & Intermediate & 399 & 43.46 \\
\hline & Upper intermediate & 330 & 35.95 \\
\hline & Advanced & 101 & 11.00 \\
\hline & Expert & 42 & 4.58 \\
\hline \multirow[t]{5}{*}{ Internet skills } & Beginner & 47 & 5.30 \\
\hline & Intermediate & 399 & 45.03 \\
\hline & Upper intermediate & 307 & 34.65 \\
\hline & Advanced & 95 & 10.72 \\
\hline & Expert & 38 & 4.29 \\
\hline \multirow[t]{4}{*}{ Time spent daily on Internet } & None & 62 & 6.79 \\
\hline & $1-2 \mathrm{~h}$ & 675 & 73.93 \\
\hline & $3-4 h$ & 143 & 15.66 \\
\hline & More than $5 \mathrm{~h}$ & 33 & 3.61 \\
\hline \multirow[t]{2}{*}{ Using Facebook } & Not using & 626 & 68.72 \\
\hline & Using & 285 & 31.28 \\
\hline \multirow[t]{2}{*}{ Using Twitter } & Not using & 238 & 26.47 \\
\hline & Using & 661 & 73.53 \\
\hline
\end{tabular}

- Use of Twitter: Yes no No

- Average daily internet use: Never, 1-2 h, 3-4 h or $5 \mathrm{~h}$ and more.

- Computer Literacy Level: Beginner, Intermediate, Advanced or Expert.

- Internet Literacy Level: Beginner, Intermediate, Advanced or Expert.

- Willingness to Teaching: Do not like, Like a little or Like it.

- Willingness to Use Computer and Internet: Do not like, Like a little or Like it.

- Beliefs about the state of the realization of Participatory Democracy in the country: None, Rarely, Sometimes, Often or Always.

- The best option related to the state of sharing in social media: No hesitation to share my opinions, Sharing opinions when feeling comfortable and secure or having a hesitation to share. 


\subsubsection{The antecedents of applicability of E-democracy in schools}

The instrument developed by Ar1 (2014) was adapted to the context of the study. There were 26 items in the original questionnaire for the applicability of e-democracy in schools. The data were collected from 920 inservice teachers. Explanatory factor analysis (EFA) was then applied to identify factors. Prior to performing the analysis, the data were checked to ascertain whether or not it was appropriate for EFA. The Kaiser-Meyer-Olkin Measure of Sampling Adequacy was found to be 0.814 , and Bartlett's Test for Sphericity yielded a significant result, $\chi^{2}(231)=6309.646, p<0.001$. These results confirmed that the data was acceptable for EFA.

In the final of several rounds of EFA, Principal Component method and Promax rotation produced a four-factor solution which accounted for $49.67 \%$ of the total variance. The analysis commenced with 26 items and was completed with 22 items, after four items were removed. The details of the factors are presented in Table 2.

The overall reliability of the scale was found to be 0.81 , which indicates a satisfactory level of reliability. The factors (antecedents) and corresponding items are presented in Table 3.

It can be stated that the implementation of e-democracy in schools is composed of four component factors: (a) motivation to participate, (b) security and ethical issues, (c) administrative issues, and (d) infrastructure and platforms. The participants' scores from the application of this instrument were calculated by saving regression scores during the EFA, and those scores were then used for further analyses.

\subsubsection{The level of applicability of E-democracy in schools}

This section contained a single item asking the participants to choose the options listed below:

- I believe that e-democracy will never be applied in schools.

- I believe that e-democracy will be applicable at the initial level via presenting and stating our opinions to the administrators.

Table 2 Factor loadings

\begin{tabular}{llllll}
\hline Factors & $\begin{array}{l}\% \\
\text { Variance } \\
\text { explained }\end{array}$ & $\begin{array}{l}\text { Number } \\
\text { of items }\end{array}$ & $\begin{array}{l}\text { Mini- } \\
\text { mum } \\
\text { loading }\end{array}$ & $\begin{array}{l}\text { Maxi- } \\
\text { mum } \\
\text { loading }\end{array}$ & Cronbach's $\alpha$ \\
\hline 1 & 22.73 & 9 & .458 & .840 & .84 \\
2 & 10.99 & 5 & .386 & .836 & .69 \\
3 & 9.41 & 5 & .402 & .772 & .66 \\
4 & 6.55 & 3 & .387 & .923 & .68 \\
\hline
\end{tabular}


Table 3 Determinant values of grouping variable

\section{Factor 1: Motivation to participate}

1. I believe teachers have sufficient self-confidence to participate in e-democracy applications

2. I believe I can devote time to participate in e-democracy applications (e.g., participating in discussions via the Internet)

3. I believe students are willing to participate in e-democracy applications

4. I believe parents are willing to participate in e-democracy applications

5. I believe teachers are willing to participate in e-democracy applications

6. I believe school principals are willing to participate in e-democracy applications

7. I believe Ministry of National Education District Offices are willing to participate in e-democracy applications

8. I believe school personnel other than teachers and administrators (e.g., janitors) are willing to participate in e-democracy applications

9. I believe e-democracy can be applied in classes

Factor 2: Security and ethical issues

1. I believe e-democracy applications should be used on institution-specific platforms, rather than via social networks

2. I believe e-democracy applications on social platforms such as Facebook and Twitter may cause ethical problems

3. I believe using social platforms such as Twitter for e-democracy applications may cause security problems

4. I believe that the usage of e-democracy applications on institution-specific platforms (e.g., intranet) may prevent security and ethics violations

5. I believe that whatever platforms are used for e-democracy applications, there may still be security and ethical issues

Factor 3: Administrative issues

1. I believe that teachers are required to be technology-literate in order to participate in e-democracy applications

2. I believe the current perception of administrators related to democracy is a major obstacle to e-democracy applications

3. I believe that although e-democracy applications are initiated, administrators will not respect the outcome of the decisions reached

4. I believe that administrators are required to participate more in e-democracy applications and to consider and respect the outcome of the decisions reached

5 . I believe that the overall government policy related to e-democracy is insufficient

Factor 4: Infrastructure and platforms

1. I believe that the current computer and Internet facilities are sufficient to initiate e-democracy applications

2. I believe that e-democracy applications can be initiated via social networks such as Facebook

3. I believe that e-democracy applications can be initiated via social networks such as Twitter

- I believe that e-democracy will be applicable at a deliberative level in online environments where all stakeholders can make a decision by arguing.

\section{Findings}

Discriminant function analysis is a statistical technique used to determine which predictor variables discriminate between two or more naturally occurring groups (Garson, 2012; Ho, 2014; Tabachnick \& Fidell, 2013). A multiple stepwise discriminant 
function analysis was performed using the antecedents of e-democracy in schools (motivation to participate, security and ethical issues, administrative issues, and infrastructure and platforms), participants' demographic characteristics (gender, school type where currently working, years of experience in teaching, and education level), technology usage attributes (use of Facebook and Twitter, daily hours of Internet usage, basic computer and Internet skills, and attitude towards computer and Internet use), attitude towards the teaching profession, level of participatory democracy in the country, and sharing on social media as predictors of membership in the beliefs in the applicability level of e-democracy in schools whose groups were never applicable (G1), applicable at initial level (G2), applicable at deliberative level (G3).

For the remaining 765 cases (184 never applicable, 391 applicable with reporting and declaration to managers, and 190 applicable within online platforms), evaluation of assumptions of linearity, normality, multicollinearity, and singularity were found to be satisfactory. Statistically significant heterogeneity of variance-covariance matrices $(p<0.001)$ were observed. Garson (2012) indicated that violation of this assumption can frequently be seen in large sample sizes. Moreover, Ho (2014) criticized Box's M-test due to its high sensitivity to factors (e.g., normality of variables) other than just covariance differences. In order to determine whether or not this violation could affect the DFA results, the log determinants of each group were checked to ensure that they were not substantially differentiated. Table 4 presents the log determinant values, which shows that there was no substantiated difference established. Thus, significant heterogeneity of variance-covariance matrices could be ignored (Garson, 2012). Moreover, when equality of covariance assumption has been violated, another remedy is to use separate group covariance rather than within-group covariance (Tabachnick \& Fidell, 2013). The DFA analysis results were therefore double-checked using both of these options, and the results were not found to alter drastically.

Two discriminant functions were calculated using a combined Wilk's $\lambda=0.809$, $\chi^{2}(8)=160.886, p<0.001$. After removal of the first function, there was still a strong association found between the groups and predictors, Wilk's $\lambda=0.963$, $\chi^{2}(3)=28.307, p<0.001$. For the first discriminant function, canonical $\mathrm{R}^{2}$ was established as being 0.16, whilst for the second discriminant function, canonical $\mathrm{R}^{2}$ was 0.0365 . Thus, the two functions accounted for approximately $16.00 \%$ and $3.65 \%$ of the total relationship between predictors and between groups, respectively. The two discriminant functions accounted for $83.4 \%$ and $16.6 \%$, respectively, of between-group variability. Figure 1 illustrates how two functions differentiated the

Table 4 Log determinant values of grouping variable

\begin{tabular}{ll}
\hline $\begin{array}{l}\text { Perception of applicability level of e-democracy } \\
\text { in schools }\end{array}$ & Log determinant \\
\hline Never applicable (G1) & -1.620 \\
Applicable at initial level (G2) & -2.556 \\
Applicable at a deliberative level (G3) & -1.448 \\
Pooled within-groups & -1.957 \\
\hline
\end{tabular}




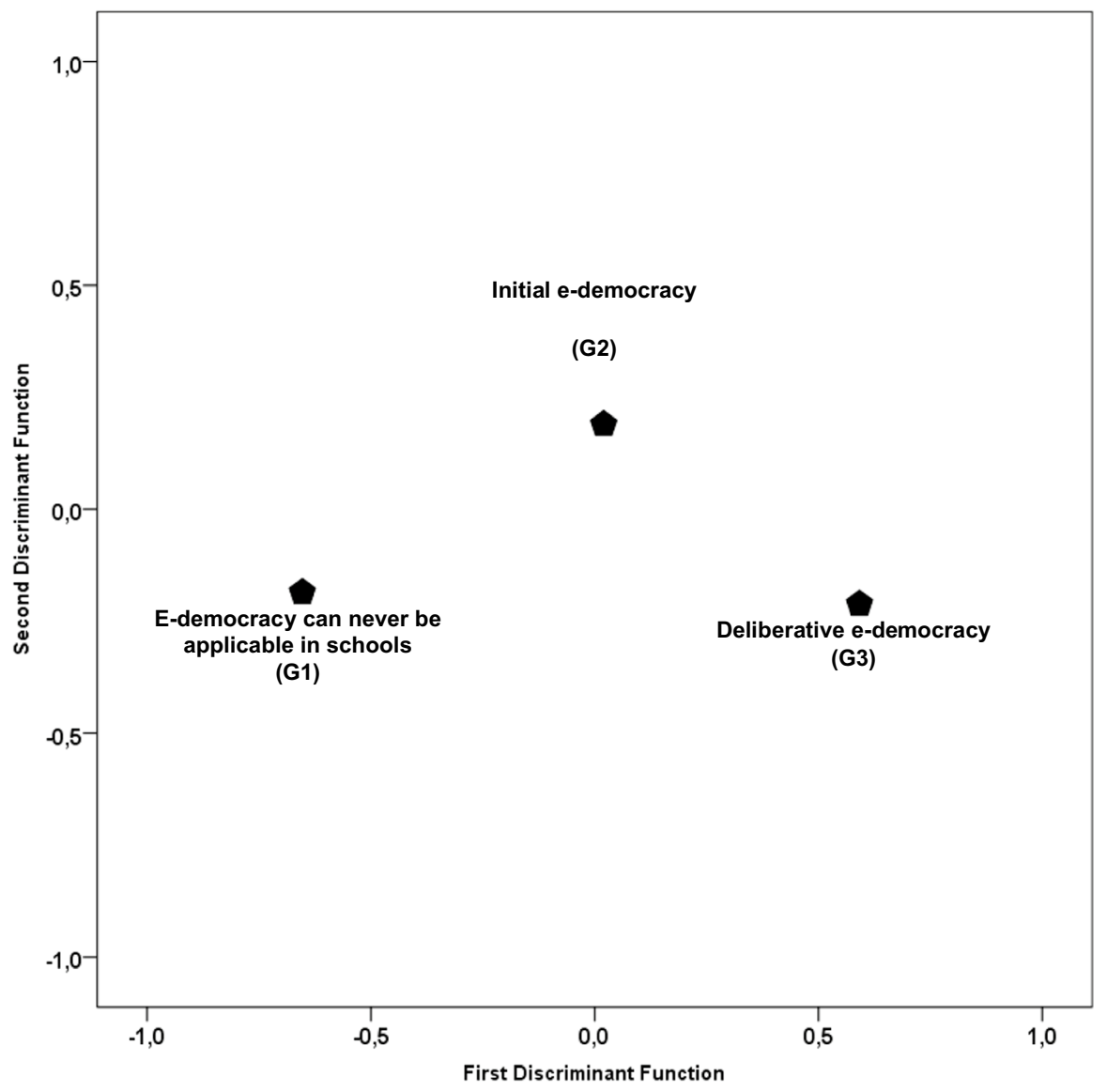

Fig. 1 Unstandardized canonical discriminant functions evaluated at group centroid means

centroid means of the three groups. The first discrimination function discriminates the three groups from each other. The second discrimination function maximally discriminates the beliefs that e-democracy can be applicable at initial level from the other two groups.

The structure (loading) matrix of correlations between predictors and discriminant functions are illustrated in Table 5. The results suggest that, in order of importance, the best and significant predictors for differentiating the three groups from each other (first function) are "motivation to participate," "level of participatory democracy in the country," and "use of Twitter." In order of importance, "security and ethical issues" and "use of Twitter" significantly differentiate the beliefs that e-democracy can be applicable at initial level from the other two groups.

Inspection of groups means presented in Table 5 evidently indicates that the three groups differed significantly in the way they perceive "motivation to participate," "security and ethical issues," "level of participatory democracy in the country," 


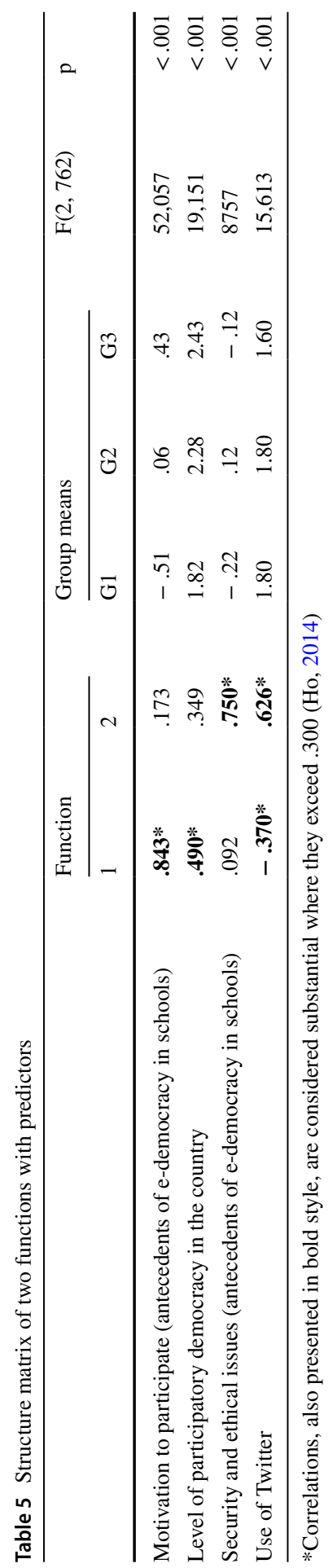


and "use of Twitter." More specifically, as far as the first discrimination function is considered, those who believed that e-democracy can be applicable at a deliberaitve level (G3) held a higher opinion that "motivation to participate" was the most critical compared to the other two groups (G1 and G2). Moreover, the same group (G3) also thought that the "current level of participatory democracy in the country" was encouraging when compared to the other groups (G1 and G2). Finally, this same group (G3) had a higher "usage rate of Twitter" compared to the other two groups (G1 and G2). In the second discrimination function, those who believed that e-democracy can be applicable at initial level(G2) had the highest mean score with respect to the other two groups (G1 and G3). Moreover, the same group (G2) used Twitter as equal as those who believed in e-democracy can never be applicable (G1), but lower than those who believed that e-democracy can be applicable at a deliberative level (G3).

Table 6 illustrates the confusion table between predicted group and observed group membership (original and cross-validated), including prior probabilities computed from group sizes. The results suggest that $56.2 \%$ (55.2\% cross-validated) of cases were correctly classified. Inspection of the classification table reveals that there was $84.9 \%$ (83.6\% cross-validated) correct classification for the group believing in the "application of e-democracy with reporting and declaring to administrators." On the other hand, there was just $25.0 \%$ (23.9\% cross-validated) and $27.4 \%$ ( $26.8 \%$ cross-validated) for groups believing in "e-democracy never applicable," and "appliciable at a deliberative level," respectively.

The final step of determining predictive ability was to test classification accuracy by demonstrating evidence for the discriminatory power of the classifications as better than chance (Ho, 2014). Press's Q-statistic was used with a chi-square critical value of 6.63 , with one degree of freedom $(p<0.01)$. For both original and cross-validated classifications, Q-statistics were calculated as 256.95 (261.88 crossvalidated), 34.88 (30.49 cross-validated), and 242.41 (244.8 cross-validated) for the three groups (G1, G2, and G3), respectively. Since the of the all values were higher than the critical value, all of the classifications were deemed to be better than chance $(p<0.01)$.

\section{Discussion and conclusion}

Considering the current study's findings in general, 184 participants believed that e-democracy could never be implemented in schools, 391 participants stated it could be implemented at initial level, whilst 190 participants stated that it could be implemented at a deliberative level. The collected data showed that over half of the participants believe that e-democracy, in the K-12 schooling context, can be implemented via reporting views and ideas. The study's DFA results showed that "motivation to participate," "level of participatory democracy in the country," and higher-level "use of Twitter" are significant determinants of different levels of e-democracy applications. In order to reach the highest level of e-democracy (deliberative e-democracy) in K-12 schools where all stakeholders reach decisions via discussion, the motivation of stakeholders to participate is recognized as the most critical factor by the 


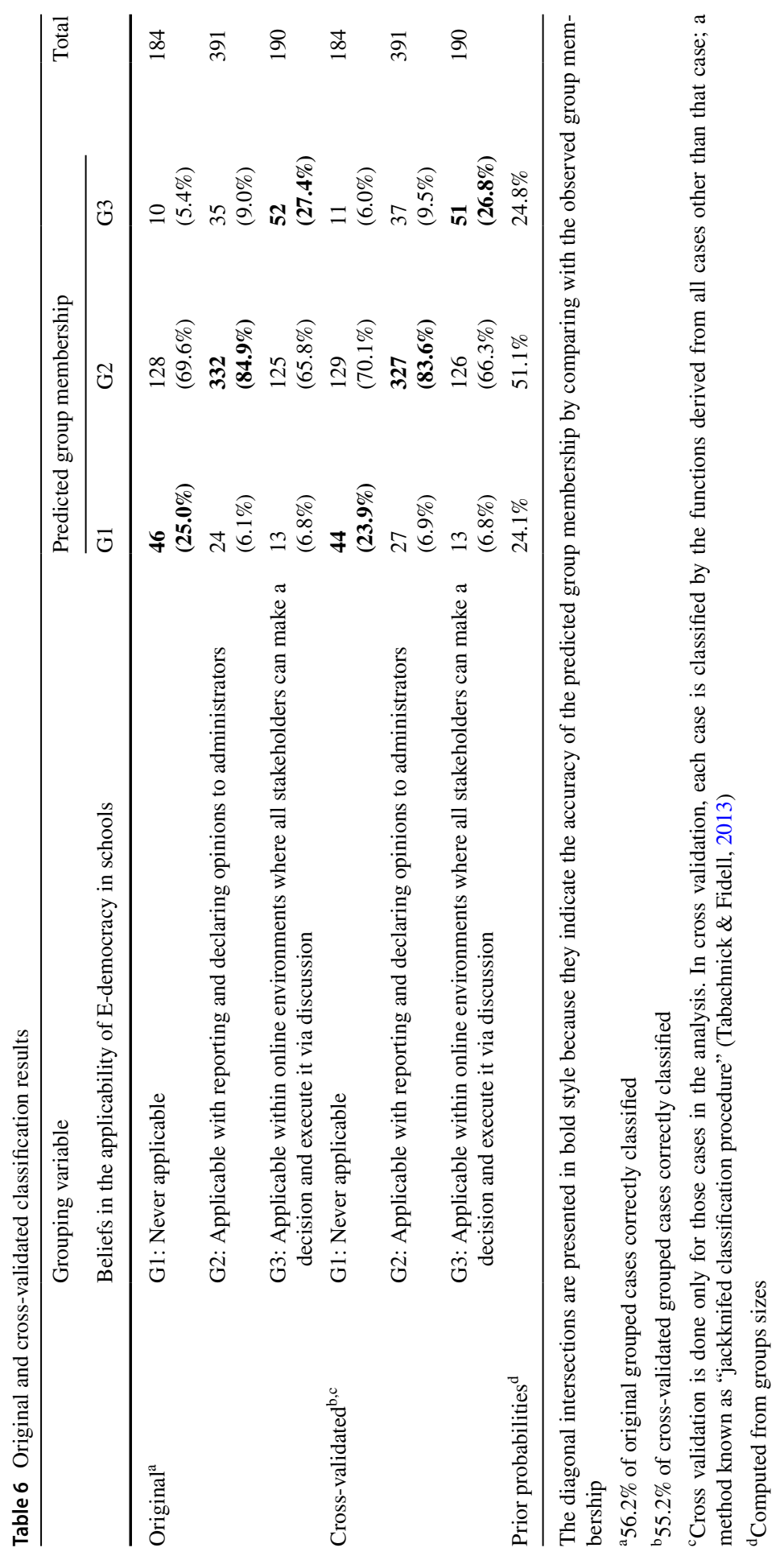


participants. Those participants who held the opinion that the current level of participatory democracy in the country was high, believe that e-democracy can be applicable at the deliberative level in schools. This result implies a relationship between "the level of participatory democracy in the country" and "motivation to participate". The perception of a high level of participatory democracy in the country could be considered a motivating factor causing teachers to develop a positive attitude on achieving the deliberative e-democracy in their schools. The motivation to participate in e-democracy in schools seems to be promoted by providing a higher level of participation in democracy in the country. As a result, country-wide initiatives that improve the quality of participation in democracy may positively affect the teachers' motivation on joining in deliberative e-democracy processes in their schools. Compared to the other participants, the participants who believed that e-democracy in schools can reach the deliberative level also had the highest level of Twitter use. The study therefore suggested that there was evidence on the relationship between the use of Twitter and participation in e-democracy which is commonly argued. This finding could be as a result of the teachers' awareness of Twitter usage, which supports Lindner and Aichholzer's (2020) argument on the importance of ICT use and e-democracy. Extensive social media users may have a high level of ICT awareness. This might cause teachers to become aware of the ethical issues, and security related impacts on social media. Besides, as they may participate in political debates through Twitter, they may also have a higher level of perception regarding participatory democracy in the country since they mostly argue/debate with citizens from the same country through that platform. Therefore, stressing the critical role of Twitter as a platform of e-democracy utilization, it may be concluded that higher rates of Twitter usage might be associated with an elevated perception of participatory democracy in the country. This view might also encourage e-democracy participation to a higher level.

The current study's results showed that the second discriminant function maximally discriminates the beliefs that e-democracy can be applicable at initial level from the other two groups. The discriminants of this perception are "security and ethical issues" and the lower level "use of Twitter." More specifically, the perception of a higher level risk of security and the ethical issues associated with the lesser use of Twitter might have an impact on the occurrence of the belief that e-democracy can be applicable at initial level. Based on this result, we argue the impact of the use of Twitter on e-democracy. As stated by Martzoukou and Sayyad (2017) digital citizens tend to participate in e-democracy through informal online settings. Similarly, in this study, data showed that a majority of the teachers with lesser use of social media such as Twitter believe that e-democracy in schools can be realized at the initial level. Whilst some of the current study's participants thought that Twitter and similar platforms might cause certain ethical issues and/or security problems, some stated that there should be organization-specific platforms, such as an intranet, in order to prevent such problems from arising. There were also some participants in the current study that thought that security and ethical problems would never disappear totally, regardless of the platform/s used. Among the critical issues affecting the applicability of e-democracy are ethical issues such as privacy, security, rights, and data protection. In this regard, under the heading of social, legal, and ethical issues, 
Öztürk (2019) discussed social and personal problems originating from the Internet, such as transparency and accountability in data protection practices, ethics in a digital society, the digital divide, freedom of expression and privacy, and the use of Internet technologies by countries and other users in accordance with fundamental democratic values. Several reasons can let the teachers with lesser use of Twitter think that e-democracy at schools can be applied at the initial level instead of deliberative level. As the teachers use online social media, the discussions occurring in an informal setting usually lose the direction, and go out of the context. In school settings, deliberations should be goal-oriented rather than general discussions. As a result, goal-oriented institutional tools and platforms may serve to motivate teachers to a deliberative level of e-democracy. Moreover, creating and enabling transparent, concrete and reliable platforms for educational settings, and the countrywide efforts to improve the teachers' knowledge and skills on cyberethics and cybersecurity can foster the willingness to participate in deliberative e-democracy. On the other hand, The teachers rarely using Twitter may not feel themselves ready for online debates since they don't have much experience.

One of the findings of the current study relates to the level of participatory democracy in the country changing perceptions about the applicability of e-democracy in schools. Hence, the country's level of participatory democracy is an important tool in the transition towards e-democracy. In the study of MaierRabler and Huber (2010), it was stated that there are two mandatory prerequisites for the participation in democratic processes; individual interest and idea generation. First, new ICTs serve fundamentally as a means to access information, which helps to ensure citizen participation and thereby facilitating democracy. However, access to information alone is insufficient for the applicability of e-democracy; instead, people need to acquire certain digital skills and related literacy in order to acquire the information they seek. Digital technologies concretize the link between access to information and literacy, which equates to motivation for and interest in political and civic engagement. On Internet- and network-based platforms, individuals are brought "closer together," and users learn how to apply new technologies and social media, to develop and increase their political awareness, and thus to increase the country's level of participatory democracy. Increased motivation and guidance are needed so as to encourage the teachers to utilize digital platforms for participatory purposes, and as one of the practices that can affect participation level in the country. As a result, The teachers' ability to exploit the emerging ICTs may serve as a venue to reach at the highest level of e-democracy in schools. Policy makers dealing with schooling systems should recognize the value of this point. On the other side of the argument, it can be also predicted that e-democracy would increase participation in democracy. Freeman and Quirke (2013) stated that though social network applications can influence political agendas within the scope of e-democracy, they may have limited effect on directly shaping the decision-making process when compared to government initiated e-democracy efforts. Hence, it becomes important for governments to provide space for democratic e-participation in order to protect their legitimacy by considering increased external pressures, as well as increased public debate and scrutiny. Thus, we can argue a potential reciprocal interaction of the quality of 
the e-democracy and the level of participatory democracy in the country. Namely, the efforts to improve participatory democracy in the country can cause improvement in the level of e-democracy while the improvements in e-democracy can facilitate a more stronger democracy. As a result, it becomes evident for governments to provide space for a higher level e-democracy to engage more teachers in the development of a deliberative democracy culture and climate in educational settings. In this context, several authors such as Petrik (2010) suggest and explain the properties of the ways and platforms that can serve to realize e-democracy.

The current study recommends performing practical implementations within schools in order to adopt the applicability of e-democracy in schools. Similarly, Marie-Rabler and Huber (2010) considered school practices as prerequisites for sustainable e-democracy and e-participation. According to them, e-participationoriented school practices are quite remarkable. For instance, integrating social platforms into the essence of formal education, that is, learning and teaching in the classroom, in a way that allows teachers and students to interact with each other in a balanced and participatory manner will increase students' motivation in democracy and political processes. A participatory teaching style that respects students' digital skills and daily social experiences can be adopted in their political education. At this point, PoliPedia, a social platform tool, is promoted as a Wiki-based tool for political education and specifically for teachers and students to collaboratively share their subjects and studies with other classes both inside and outside of the formal school environment. Using these platforms and maintaining such a collaborative method requires both teachers and students to develop their skills and media literacy (MarieRabler \& Huber, 2010). One influential study covering effective practices on the applicability of e-democracy in schools was conducted by Windischbauer (2008), in which it was considered that, in relation to e-democracy, simulation games were both useful and operative tools in the preparation of students for real-life situations, which is an example of emphasizing the crucial role of schools and education both in creating and disseminating a stronger democracy culture. However, in realizing this role, teachers need to be properly motivated as emerged from the data of the current study.

All in all, e-democracy applications are very limited, and at a very low level in educational settings in Turkey occurring mostly at the initial level. Considering pandemic conditions, the need for the realization of deliberative e-democracy in schools has become more evident. Following suggestions can be made for such developing countries' policy makers like Turkey to develop and implement the deliberative e-democracy solutions in educational settings:

- start with seeking the ways that promote motivation to realize deliberative e-democracy,

- provide a country-wide participatory democracy climate,

- consider properly using the ways of online social media andor informal/formal collaborative working platforms as a tool to realize deliberative e-democracy,

- consider improving discussion experience of stakeholders,

- consider building cyberethics and cybersecurity skills,

- provide goal-oriented institutional platforms, 


\section{References}

Abu-Shanab, E., \& Al-Dalou', R. (2012). E-participation initiatives: a framework for technical tools. Paper presented at the 2012 International Arab Conference of E-Technology (IACe-T'2012) (pp. 57-64).

Arı, İ. (2014). Perceptions of teachers in Antalya about the applicability of e-democracy in educational institutions[Unpublished master's thesis]. Akdeniz University

Ayo, C. K., Mbarika, V. W., \& Oni, A. A. (2015). The influence of trust and risk on intention to use e-democracy in Nigeria. Mediterranean Journal of Social Sciences, 6(1), 477-486. https://doi. org/10.5901/mjss.2015.v6n6s 1p477

Bailey, A., \& Ngwenyama, O. (2011). The challenge of e-participation in the digital city: Exploring generational influences among community telecentre users. Telematics and Informatics, 28(3), 204-214

Çabuk, U. C., Çavdar, A., \& Demir, E. (2016). E-Demokrasi: Yeni Nesil Doğrudan Demokrasi ve Türkiye'deki Uygulanabilirliği [E-Democracy: The Next Generation Direct Democracy and Applicability in Turkey]. Retrieved December 12, 2020 from, https://www.researchgate.net/profi le/Umut_Cabuk/publication/308796230_E-Democracy_The_Next_Generation_Direct_Democ racy_and_Applicability_in_Turkey/links/5818a6d408aee7cdc685b40b.pdf.

Chadwick, A. (2003). Bringing e-democracy back in: Why it matters for future research on e-governance. Social Science Computer Review, 21(4), 443-455.

Clive, C. (2012). Towards understanding eParticipation in the public sphere. Review of Business Research, 12(1), 140-146.

Coleman, S., \& Norris, D. F. (2005). A new agenda for e-democracy. Oxford Internet Institute. Forum Discussion Paper No. 4. Retrieved on January 7, 2014 from http://www.ukn.inettr.org.tr/oii/FD4. pdf.

Creswell, J. W. (2012). Educational research: Planning, conducting, and evaluating quantitative and qualitative research (4th ed.). Pearson Education Inc.

Cross, M. (2003). Unpopular touch: the first professor e-democracy wants to improve the UK's poor attempts at consultation. Guardian Online. Retrieved December 12, 2020 from, http://www. guardian.co.uk/technology/2003/feb/27/internet.epublic1.

Dewey, J. (1903). Democracy in education. The Elementary School Teacher, 4(4), 193-204.

Ferdinand, P. (2003). Cyber-democracy. In R. Axtmann (Ed.), Understanding democratic politics: An introduction (pp. 207-217). Sage.

Freeman, J., \& Quirke, S. (2013). Understanding e-democracy: Government-led initiatives for democratic reform. Journal of e-Democracy and Open Government, 5(2), 141-154. https://doi.org/10. 29379/jedem.v5i2.221

Garson, G. D. (2012). Discriminant function analysis. Statistical Associates.

Ho, R. (2014). Handbook of univariate and multivariate data analysis with IBM SPSS. CRC Press.

Karickhoff, M., \& Howley, A. (1997). Democracy in teacher education: Equality verses excellence. The Teacher Educator, 3(2), 61-69.

Kocór, M., Yordanova, L., van Steenbergen, J., \& Merunka, V. (2017). Zonal constructed language and education support of e-democracy-The Interslavic experience. International conference on E-democracy. In S. Katsikas \& V. Zorkadis (Eds.), E-democracy-privacy-preserving, secure, intelligent E-government services. e-Democracy 2017. Communications in Computer and Information Science (Vol. 792). Springer. https://doi.org/10.1007/978-3-319-71117-1_2

Kolfschoten, G. L. (2012). A toolbox for democratic and parcticipatory methods in education. Future Learning, 2012 (1)

Lindner, R., \& Aichholzer, G. (2020). E-democracy: Conceptual foundations and recent trends. In L. Hennen, I. Van Keulen, I. Korthagen, G. Aichholzer, R. Lindner, \& R. Nielsen (Eds.), European E-democracy in practice (pp. 11-45). Springer.

Macintosh, A., Robson, E., Smith, E., \& Whyte, A. (2003). Electronic democracy and young people. Social Science Computer Review, 21(1), 43-54.

Mærøe, A. R., Norta, A., Tsap, V., \& Pappel, I. (2021). Increasing citizen participation in e-participatory budgeting processes. Journal of Information Technology \& Politics, 18(2), 125-147.

Maier-Rabler, U., \& Huber, S. (2010). Sustainable E-Participation through participatory experiences in education. Ejournal of EDemocracy and Open Government, 2(2), 131-144. https://doi.org/10. 29379/jedem.v2i2.37 
Martzoukou, K., \& Seyyad, A. E. (2017). Towards an everyday life information literacy mind-set: A review of literature. Journal of Documentation, 73(4), 634-665.

Medimorec, D., Parycek, P., \& Schossböck, J. (2010). Vitalizing democracy through E-participation and open government: An Austrian and Eastern European perspective, bertelsmann [online]. Retrieved December 08, 2020 from, http://www.bertelsmann-stiftung.de/cps/rde/xbcr/SID4B6B2682-20BE4653/bst/Daniel\%20Medimorec.pdf.

Mompoint-Gaillard P., Cassar, C., \& Làzàr I. (2019). The role of teachers in developing democratic competence. In If not in Schools, where? Learn and Practice Democracy in eTwinning

Musiał-Karg, M., \& Kapsa, I. (2019). Attitudes of polish voters towards introduction of e-voting in the context of political factors. In S. Katsikas \& V. Zorkadis (Eds.), E-democracy-Safeguarding democracy and human rights in the digital age, proceedings of the 8th international conference, e-democracy (pp. 144-161). Springer.

Mutz, D. C. (2006). Hearing the other side: Deliberative versus participatory democracy. Cambridge University Press.

Naranjo-Zolotov, M., Oliveira, T., \& Casteleyn, S. (2019a). Citizens' intention to use and recommend e- participation. Information Technology and People, 32(2), 364-386.

Naranjo-Zolotov, M., Oliveira, T., Casteleyn, S., \& Irani, Z. (2019b). Continuous usage of e- participation: The role of the sense of virtual community. Government Information Quarterly, 36(3), 536-545.

Oni, A. A., Oni, S., Mbarika, V., \& Ayo, C. K. (2017). Empirical study of user acceptance of online political participation: Integrating civic voluntarism model and theory of reasoned action. Government Information Quarterly, 34(2), 317-328. https://doi.org/10.1016/j.giq.2017.02.003

Oral, B. (2008). The evaluation of the student teachers' attitudes toward Internet and democracy. Computers \& Education, 50(1), 437-445.

Öztürk, C. (2019). Demokrasiyi hacklemek: Siber demokrasi araçları [Hacking Democracy: Cyber Democracy Tools]. Electronic Turkish Studies, 14(4), 2625-2646. https://doi.org/10.29228/Turki shStudies. 22957

Päivärinta, T., \& Sæbø, Ø. (2006). Models of e-democracy. Communications of the Association for Information Systems, 17(1), 818-840. https://doi.org/10.17705/1CAIS.01737

Park, H. Y. (2018). Application of complexity theory to educational decision-making process: A model for democratic school change. The SNU Journal of Education Research, 27(4), 19-39.

Peart, M. N., \& Diaz, J. R. (2007). Comparative project on local e-democracy initiatives in Europe and North America. Research Centre on Direct Democracy, Faculty of Law, University of Geneva. Retrieved from http://www.ict-21.ch/com-ict/IMG/pdf/comparativeprojectsonlocaledem ocracy.pdf.

Pelletier, L. G., Séguin-Lévesque, C., \& Legault, L. (2002). Pressure from above and pressure from below as determinants of teachers' motivation and teaching behaviors. Journal of educational psychology, 94(1), 186

Peters, M. A., \& Jandrić, P. (2017). Dewey's Democracy and Education in the age of digital reason: The global, ecological and digital turns. Open Review of Educational Research, 4(1), 205-218.

Petrik, K. (2010). Deliberation and collaboration in the policy process: A Web 2.0 approach. eJournal of eDemocracy and Open Government, 2(1), 18-27.

Ronchi, A. M. (2019). E-democracy toward a new model of (inter)active society. Springer.

Şendağ, S. (2010). Pre-service teachers' perceptions about e-democracy: A case in Turkey. Computers and Education, 55(4), 1684-1693. https://doi.org/10.1016/j.compedu.2010.07.012

Şendağ, S. (2014). An e-democracy application: Do not let my dreams of an ideal university stay only in my dreams. International Journal on New Trends in Education and Their Implications, 5(1), 53-63.

Sendag, S., \& Toker, S. (2016). Factors affecting participation of preservice teachers in E-democracy. Journal of Educational Technology, 13(2), 30-46.

Sennett, R. (1999). The spaces of democracy. Harvard Design Magazine, 8, 68-72.

Shat, F., \& Pimenidis, E. (2017). E-voting vs. e-trust: A test bed for e-democracy in a world in crisis? International Journal of Electronic Governance, 9(1), 229-245. https://doi.org/10.1504/IJEG. 2017.10006254

Shelley II, M. C., Thrane, L. E., \& Shulman, S. W. (2006). Lost in cyberspace: Barriers to bridging the digital divide in e-politics. International Journal of Internet and Enterprise Management, $4(3), 228-243$ 
Shirazi, F., Ngwenyama, O., \& Morawczynski, O. (2010). ICT expansion and the digital divide in democratic freedoms: An analysis of the impact of ICT expansion, education and ICT filtering on democracy. Telematics and Informatics, 27(1), 21-31.

Tabachnick, B. G., \& Fidell, L. S. (2013). Using multivariate statistics (6th ed.). Pearson.

Toots, M. (2019). Why E-participation systems fail: the case of Estonia's Osale.ee. Government Information Quarterly, 36(3), 546-559.

United Nations General Assembly. (2015). Transforming our world: The 2030 agenda for sustainable development. UN Resolution A/RES/70/01. Retrieved December 12, 2020 from https://undocs. org/A/RES/70/1.

Ünlü, H. (2017). Internet and democracy: Is the Internet an important predictor for physical education teacher candidates' attitudes towards democracy? Cogent Education. https://doi.org/10.1080/ 2331186X.2016.1275088

Van Long, T. (2020). Realizing the barrier to the practice of e-democracy in Vietnam. PalArch's Journal of Archaeology of Egypt/Egyptology (PJAEE), 17(3), 355-370.

Windischbauer, E. (2008). Probehandeln in Simulationsspielen [Probes in simulation games]. Kompetenzorientiere Politische Bildung, 29, 69-73.

Wojcieszak, M. E., Baek, Y. M., \& Carpini, M. X. D. (2010). Deliberative and participatory democracy? Ideological strength and the processes leading from deliberation to political engagement. International Journal of Public Opinion Research, 22(2), 154-180. https://doi.org/10.1093/ijpor/ edp050

Yiğit, E. Ö., \& Çolak, K. (2010). The opinions of the pre-service teachers about e-democracy in Turkey. Procedia-Social and Behavioral Sciences, 2(2), 712-716.

Publisher's note Springer Nature remains neutral with regard to jurisdictional claims in published maps and institutional affiliations.

\section{Authors and Affiliations}

\section{Serkan Sendag ${ }^{1}$ (D) $\cdot$ Sacip Toker $^{2}$ (D) Lutfi Uredi $^{3}$ (D) Omer Faruk Islim ${ }^{4}$}

Serkan Sendag

serkansendag@mersin.edu.tr

Sacip Toker

sacip.toker@atilim.edu.tr

Lutfi Uredi

lutfiuredi@mersin.edu.tr

1 Computer Education and Instructional Technology, Mersin University, Mersin, Turkey

2 Information Systems Engineering, Atilim University, Ankara, Turkey

3 Primary Education, Mersin University, Mersin, Turkey

4 Computer Technologies, Mersin University, Mersin, Turkey 